\title{
Early Invasive Cervical Squamous Cell Carcinoma
}

National Cancer Institute

\section{Source}

National Cancer Institute. Early Invasive Cervical Squamous Cell Carcinoma. NCI

Thesaurus. Code C36094.

A cervical squamous cell carcinoma with minimal stromal invasion. The risk of lymph node metastasis is low. 